\title{
ICING ON A NON-ROTATING CYLINDER UNDER CONDITIONS OF HIGH LIQUID WATER CONTENT IN THE AIR: I. FORM AND SIZE OF ICE DEPOSITS
}

\author{
By JOUKO LAUNIAINEN \\ (Department of Geophysics, University of Helsinki, Fabianinkatu 24 A, SF-00100 Helsinki 10, Finland) \\ and MARKKU LYYRA
}

(Institute of Marine Research, Box 33, SF-00931 Helsinki, Finland)*

\begin{abstract}
Ice accretion on a non-rotating cylinder was studied under icing conditions involving a wet-growth (glaze) process. Experiments were performed in an outdoor wind tunnel designed for icing studies. In this paper, the experimental method is introduced and the characteristics of form, size, and time development of deposits are given. In terms of freezing conditions, these characteristics were found to be very complex, in which all the external effects: air temperature, wind conditions, liquid water content in the air, and accretion time, are of the same order of importance. In a wet-growth process there exists above the icing surface a water film, the behaviour and dynamics of which are affected by various variables. The water film seems to play an important role in the wet-growth icing.
\end{abstract}

RÉSUMÉ. Givrage d'un cylindre immobile lorsque la teneur en eau liquide de l'air est importante: I. Forme et taille du dépôt de glace. L'accrétion de glace sur un cylindre ne pouvant pas tourner a été étudiée dans des conditions de givrage humide (verglas). Les expériences ont èté conduites dans une soufflerie extérieure conçue pour l'étude du givrage. Dans cet article la mèthode expérimentale est décrite ainsi que forme, taille et développement des dépóts. En termes de conditions de givrage ces caractéristiques des dépôts sont très complexes, tous les facteurs: température de l'air, conditions de vent, teneur en eau liquide de l'air et temps d'accrétion ont une

\section{INTRODUCTION}

The problem of ice accretion on structures (ships, towers, helicopters, aeroplanes, etc.) originating from breaking water waves, as well as from atmospheric fog, has increased significantly during recent years, especially due to increasing activities in polar regions. Theoretical studies (Cansdale and McNaughtan, 1977; List, 1977; Ackley and Templeton, 1979; Lozowski and others, 1979, 1983[a]), experiments and verifications (Lozowski and others, 1979, 1983[b]; Bain and Gayet, 1982) have led to a greater understanding of ice-accretion mechanisms. Most of these icing studies have involved the use of a cylinder exposed to supercooled water droplets, which are eventually mixed with snow and ice crystals. However, a knowledge of icing, especially as a wet-growth process, i.e. when all the impinging water does not freeze but runs off, seems to be insufficient. This has been seen clearly in experimental verification tests by Lozowski and others (1979, 1983[b]) and Launiainen and others (1983).

This paper describes icing and heat transfer, especially in stationary wet-growth conditions. Part I describes the

*Present address: Department of Geophysics, University of Helsinki, Fabianinkatu 24 A, SF-01000 Helsinki 10, Finland. importance comparable. Dans un processus de croissance humide il existe, á la surface du givre, un film d'eau dont le comportement et la dynamique sont régis par différentes variables. Le film liquide semble jouer un rôle important dans le givrage humide.

ZUSAMMENSFASSUNG. Vereisung eines nicht rotierenden Zylinders bei hohem Gehalt an flüssigem Wasser in der Luft: I. Form und Grösse der Eisablagerungen. Unter Vereisungsbedingungen, die einen feuchten Wachstums(Glasur-) Prozess einschlossen, wurde das Anwachsen von Eis an einen nicht rotierenden Zylinder untersucht. Die Versuche wurden in einem Windkanal im Freien, der für Vereisungsstudien gebaut worden war, vorgenommen. In diesem Beitrag wird die Versuchsmethode erklärt; die Charakteristiken für Form, Grösse und zeitliche Entwicklung werden mitgeteilt. Hinsichtlich der Gefrierbedingungen ergaben sich diese Charakteristiken als sehr komplex; alle äusseren Einflussgrössen wie Lufttemperatur, Windverhältnisse, Gehalt der Luft an flüssigem Wasser, Anwachszeit erwiesen sich als gleich bedeutungsvoll. In einem feuchten Wachstumsprozess besteht über der Vereisungsoberfläche ein Wasserfilm, dessen Verhalten und Dynamik von verschiedenen Variablen beeinflusst werden. Der wasserfilm scheint bei dem feuchten Vereisungsprozess eine wichtige Rolle zu spielen.

experimental method and outlines general form, size, and structure characteristics of the deposits grown; Part II concentrates on heat transfer during icing and on the rate of icing. The experiments were performed in a wind tunnel designed for icing tests. The tests were carried out during the winters of 1982-83 and 1983-84. Preliminary results had been reported earlier by Launiainen and others (1983).

\section{EXPERIMENTAL METHOD}

Figure 1 depicts the wind tunnel used in the study The tunnel is located outdoors and has a total length of $7.5 \mathrm{~m}$. The distance of the water-spray nozzles (two vertical nozzles) from the test object is $3.5 \mathrm{~m}$. The diameter of the main tube is $1.0 \mathrm{~m}$ and that of the test chamber $0.7 \mathrm{~m}$. The $15 \mathrm{~kW}$ motor and axial fan are capable of producing wind speeds from 5 to $28 \mathrm{~m} / \mathrm{s}$. The wind speed can be adjusted. Because the wind tunnel is outdoors, the air temperature and humidity cannot be regulated. The air temperature is measured outside and inside the tunnel; a temperature sensor is located inside the tunnel close to the spray nozzles and measures the up-stream temperature in "dry" air. Depending on the relative humidity, i.e. the saturation deficit of water vapour, apparent evaporation from the water spray was found to occur, thus cooling the moist air in the down-stream section. Due to this, icing at 


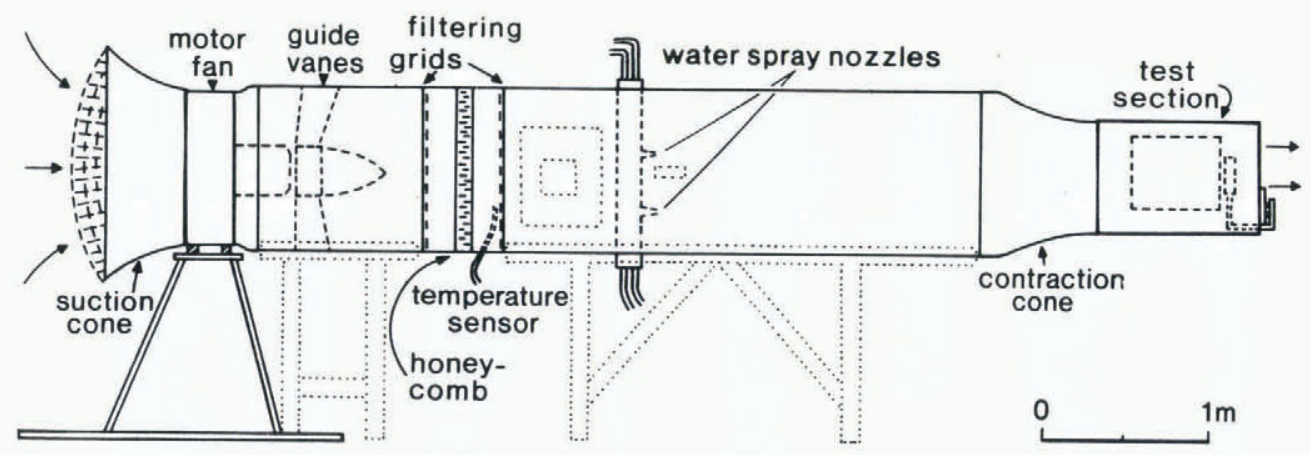

Fig. 1. Wind tunnel used for icing experiments.

air temperatures somewhat above $0^{\circ} \mathrm{C}$ are frequently observed (cf. Launiainen and others, 1983).

The water spray in the tunnel is produced by water and air passing through nozzles. The pressure values for each water-flow rate were chosen so that the median volume diameter (MVD) of the droplets (according to the nozzle manufacturer) was about $60 \mu \mathrm{m}$. Unfortunately, it was not possible to calibrate the MVD for this study.

The liquid water content and its distribution in the air was calibrated against wind speeds and pressure adjustments using a rotating cylinder (cf. Stallabrass, 1978) of $19 \mathrm{~mm}$ diameter as a collector, cooled to $-70^{\circ} \mathrm{C}$ by filling the cylinder with solid carbon dioxide. The final liquid water content $(W)$ was calculated using these calibration data, taking into account the evaporation losses discussed above. These calibration procedures have been described in more detail by Lyyra and Launiainen (in press). The water-droplet collection efficiency was calculated by using an algorithm by Lozowski and others (1979), based on a theory by Langmuir and Blodgett (1946), and using the droplet-diameter distribution given by the manufacturer. In a special study, the intensity of the free-stream turbulence was found to be less than $1 \%$. A more detailed description of the experimental method has been given in a technical report (Lyyra and Launiainen, in press).

Smooth vertical non-rotating hollow aluminium or PVC-coated Styrox cylinders $20 \mathrm{~cm}$ long and $5 \mathrm{~cm}$ in diameter were the most frequently used collectors in the icing tests. Some tests were carried out using both horizontal cylinders and cylinders $2.8 \mathrm{~cm}$ in diameter. Wind velocities from 7.5 to $20 \mathrm{~m} / \mathrm{s}$ were used, the Reynolds number thus being $2.6 \times 10^{4}$ to $7 \times 10^{4}$. The liquid water content varied from 1 to $10 \mathrm{~g} / \mathrm{m}^{3}$, thus involving a wet-growth process in most cases. The ambient air temperature varied between $0^{\circ}$ and $-13^{\circ} \mathrm{C}$. A characteristic test duration was 2-30 min and a few time series were performed. The tests were carried out by turning an arm with a test cylinder into on and off positions, across a stationary flow field.

The geometric characteristics of the ice deposits were measured, and the amount of ice was measured by weighing a cut piece, homogeneous in the vertical direction, and about $15 \mathrm{~cm}$ long. Photographs were taken, some time series were video taped, and a few samples were taken for crystallographic studies.

In the tests, a rather large liquid water content and median volume diameter was used for several reasons. Our tunnel was designed primarily for studies of marine icing, involving large MVD and large liquid water content, and the use of vertical cylinders for simulating icing on masts and rigging. (In fact, our equipment did not allow very small droplets and liquid water contents to be used, without icing problems in the nozzles!) Furthermore, for large MVDs, the collection efficiency $(E)$ is large and $\Delta E=f(\Delta \mathrm{MVD})$ is small, and thus errors for large MVDs in calculating the collection efficiency may be assumed to be smaller and less probable. These errors may arise due to the application of Langmuir and Blodgett (1946) smooth-surface theory to more or less rough ice-deposit surfaces and, due to potential errors (such as the evaporation effect) in MVD. In our quantitative and thermophysical studies, however, a quantity of water-mass flux $R_{\mathrm{w}}=E W V$, not the collection efficiency itself, is a quantity of primary importance and that flux is given by the experimental rotating cylinder calibration procedure discussed.

The temperature of the injected water was close to zero but, when it reached $20^{\circ}$ to $30^{\circ} \mathrm{C}$, no significant qualitative or quantitative effect was observed in the results, at least not at air temperatures below $-5^{\circ} \mathrm{C}$. This observation is compatible with the results of the application of the heat-balance models of a moving droplet (Panov, 1974; Zarling, 1980), according to which the droplets lost their thermal energy excess very rapidly. Typically, in our tests, this energy can affect the tunnel air temperature by $<5 \%$.

\section{FORM AND SIZE CHARACTERISTICS OF THE ICE DEPOSITS}

The most important external factors controlling ice growth and structure of a deposit under icing conditions are air temperature $\left(T_{\mathrm{a}}\right)$, wind speed $(V)$, liquid water content in the air $(W)$, and time $(t)$.

The experimental icing conditions were characterized by a rather large liquid water content and therefore wetgrowth conditions were the most frequent, i.e. all the impinging water does not freeze but runs off (cf. the section on "basic theoretical concepts" in Part II). An ice deposit normally grows faster under such conditions and becomes larger and more glaze-like (or becomes spongy) than in dry-growth conditions (cf. List, 1977; Bain and Gayet, 1982; Lozowski and others, 1983[b]). There is very little laboratory data on such conditions and so we shall outline some main characteristics of wet-growth ice deposits.

A typical wet-growth icing on a non-rotating cylinder can be seen in Figures 2 and 3 , which show the time development of two deposits grown at different liquid water contents. Figures 4 and 5 show deposits grown during $15 \mathrm{~min}$ experiments under various meteorological conditions.

The typical shape of a deposit remains cylindrical (Figs 2 and 3) for a few (3-4) min. After 1.5-4 min from the beginning of an experiment, small protuberances of 1-3 mm diameter begin to form, most frequently on a sector situated from $30^{\circ}$ to $50^{\circ}$ from the stagnation line. The excess water glides sideways down to the area of the separation of the flow field and forms wave-like deposits on the sides. A very large $W$ may yield smooth wave-like forms in the front deposit. After $4-6 \mathrm{~min}$, the deposit area, excluding just the stagnation area, is covered by protuberances of 2-5 mm. Thereafter, both sides will grow faster than the low-shear stagnation area and a stagnation hollow, most frequently a smooth one, begins to develop. A deposit received its overall structure 9-10 min from the beginning, after which it grows merely in dimensions (cf. Figs 3 and $6 a)$. During this phase, roughness elements of scales $0.1-1 \mathrm{~cm}$ can be found, and in very long tests ( $>30 \mathrm{~min}$ ) the final form may be rather irregular. The stagnation hollow is then frequently irregular and narrow.

It is worth observing that in dry-growth conditions and in proper conditions of periodic irrigation (revealed from a special set of experiments which are not reported in this 


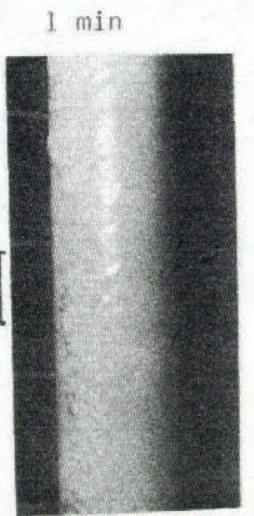

2 min
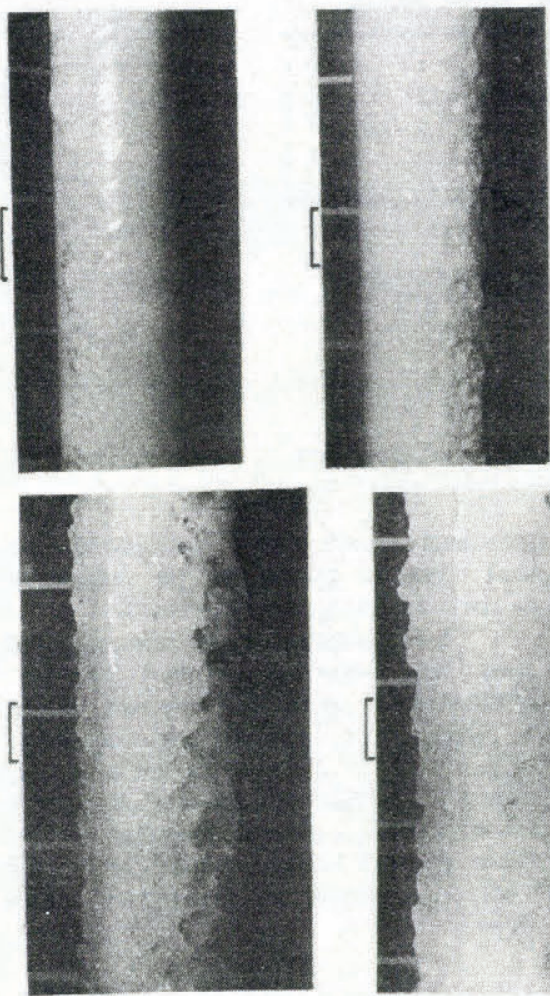

$7 \mathrm{~min}$

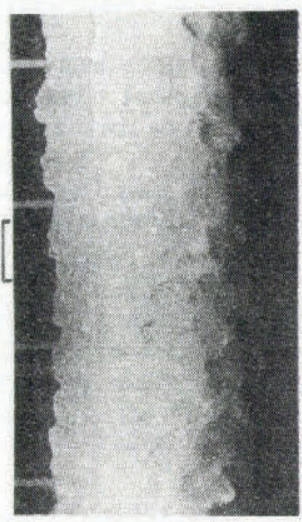

9 min
3 min
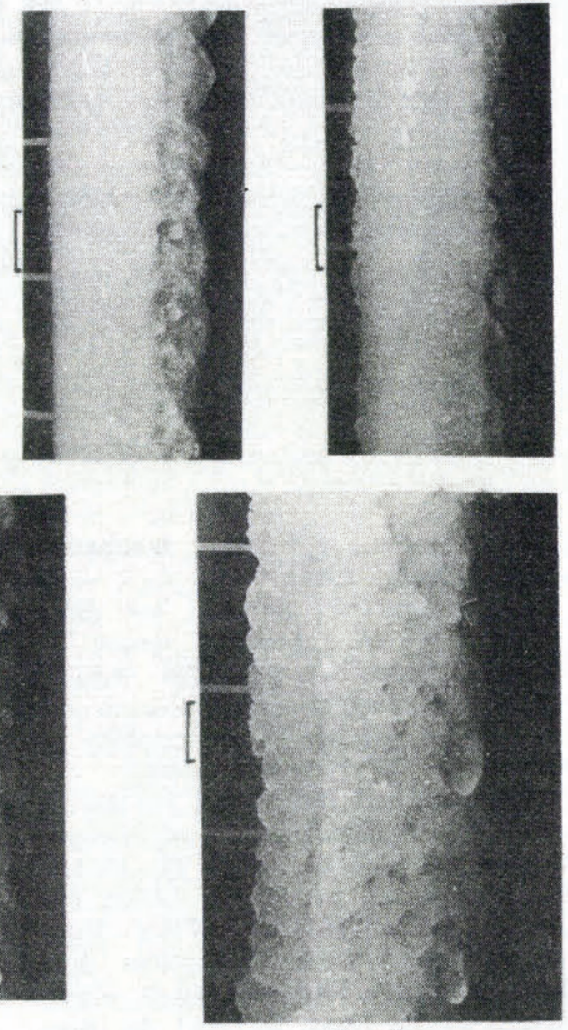

$15 \mathrm{~min}$

Fig 2. Time development of deposits under icing conditions with wind speed of $15 \mathrm{~m} / \mathrm{s}$, air temperature of $-13^{\circ} \mathrm{C}$, and liquid water content of $7 \mathrm{~g} / \mathrm{m}^{3}$, as seen $45^{\circ}$ from the stagnation line on the left. In the pictures, a scale of $2 \mathrm{~cm}$ is given.

3 min
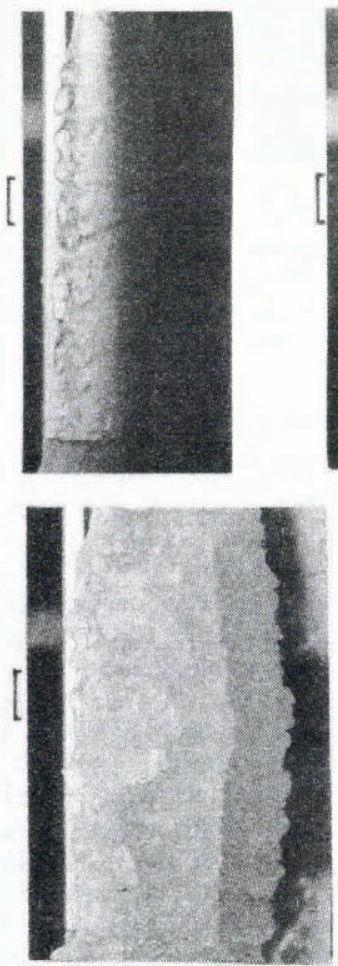

$30 \mathrm{~min}$
$6 \mathrm{~min}$

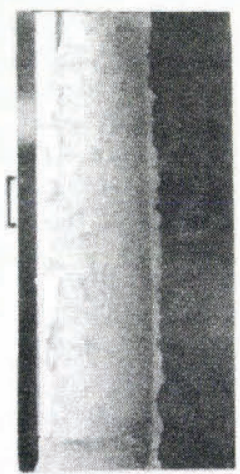

$10 \mathrm{~min}$

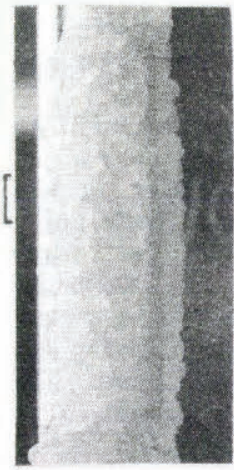

$20 \mathrm{~min}$

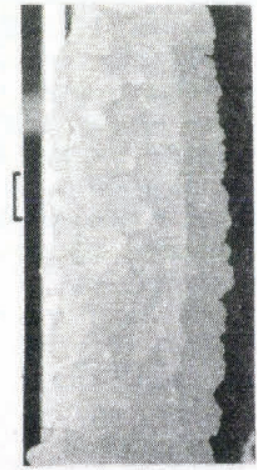

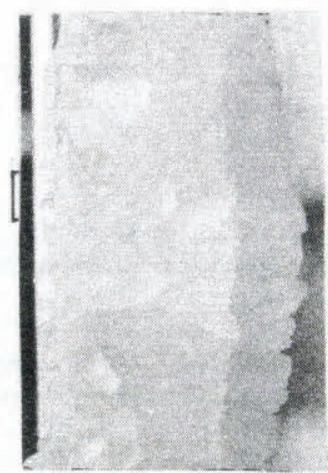

$40 \mathrm{~min}$

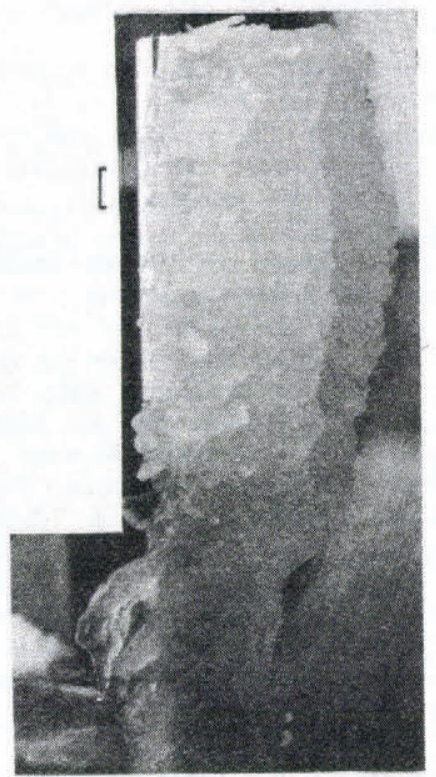

$50 \mathrm{~min}$

Fig. 3. Time development of a deposit grown under icing conditions with wind speed of $15 \mathrm{~m} / \mathrm{s}$, air temperature of $-8^{\circ} \mathrm{C}$, and liquid water content of $4.8 \mathrm{~g} / \mathrm{m}^{3}$. Scale of $2 \mathrm{~cm}$ is given. 

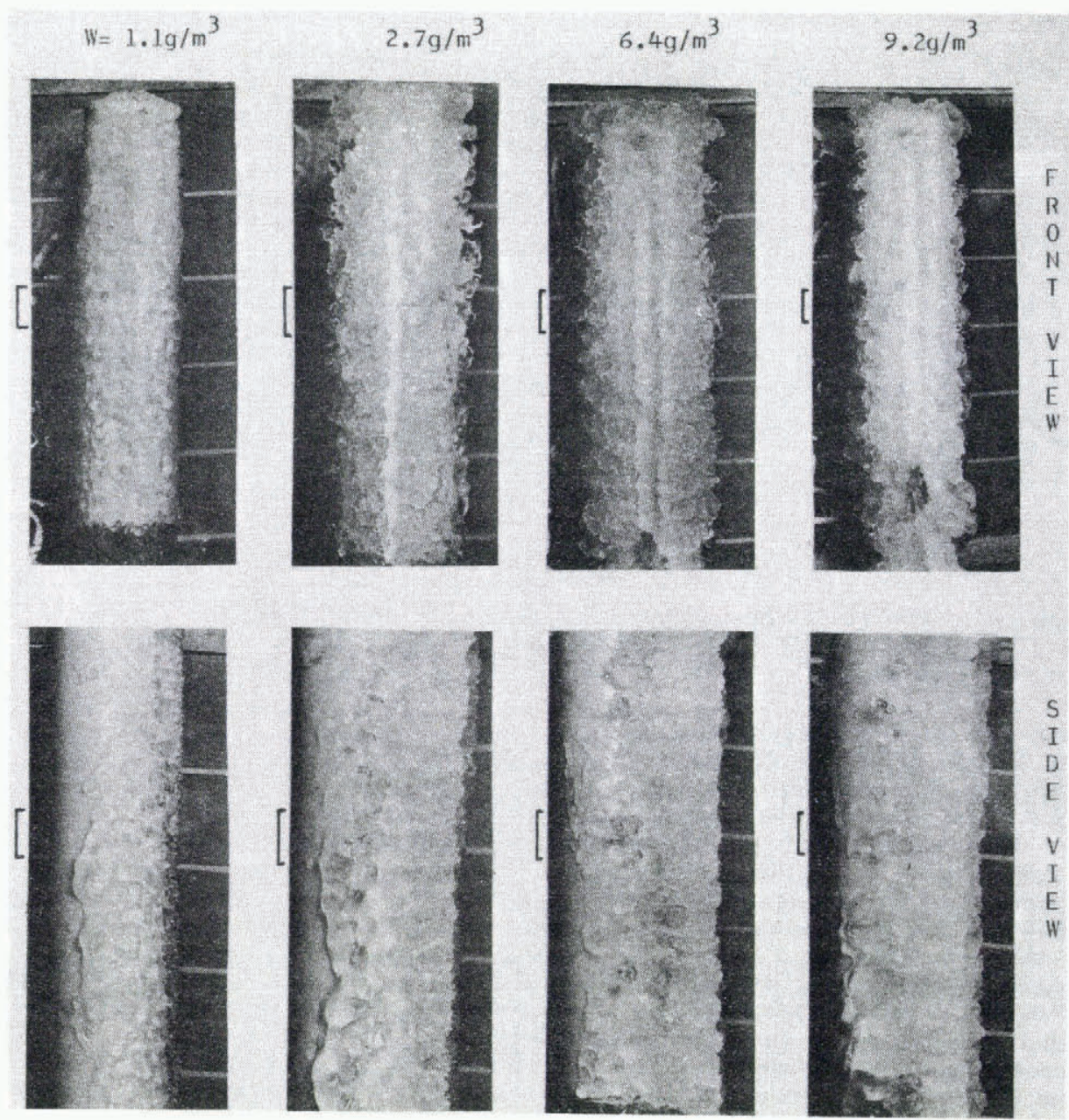

Fig. 4. Icing deposits grown under conditions of various liquid water contents, and at $15 \mathrm{~m} / \mathrm{s}$ wind speed and $-5^{\circ} \mathrm{C}$ air temperature. Test duration $15 \mathrm{~min}$. Scale of $2 \mathrm{~cm}$ is given. $10_{\mathrm{s}}^{\mathrm{m}},-5.6^{\circ} \mathrm{C}$
$0.7 \mathrm{~g} / \mathrm{m}^{3}$
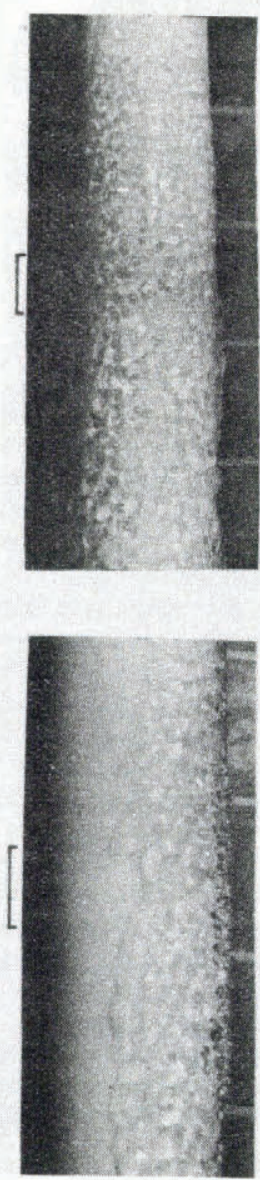

$3.0 \mathrm{~g} / \mathrm{m}^{3}$
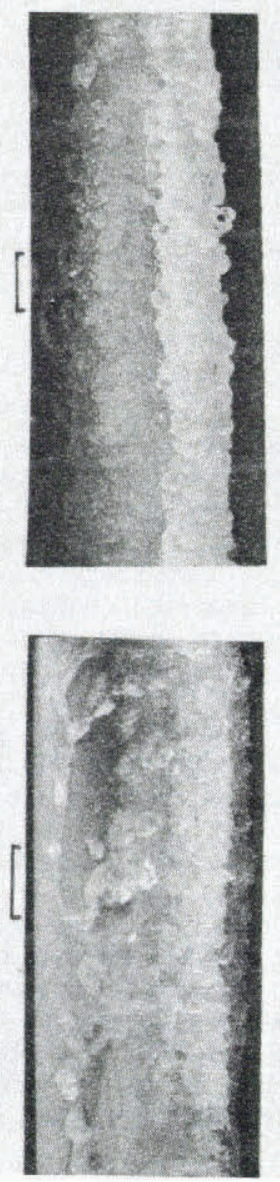

$7.4 \mathrm{~g} / \mathrm{m}^{3}$
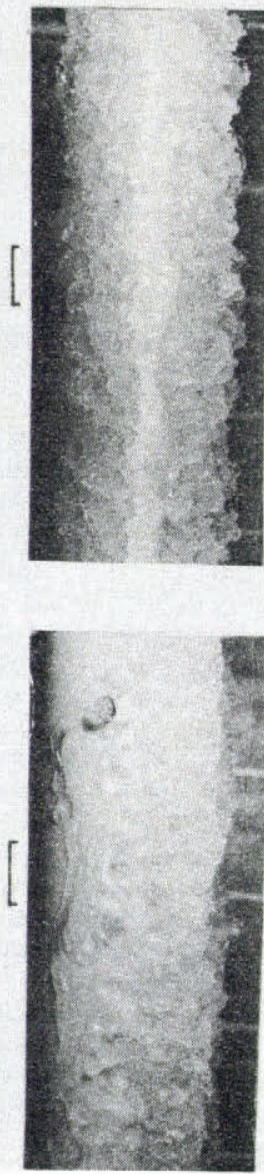

$9.8 \mathrm{~g} / \mathrm{m}^{3}$
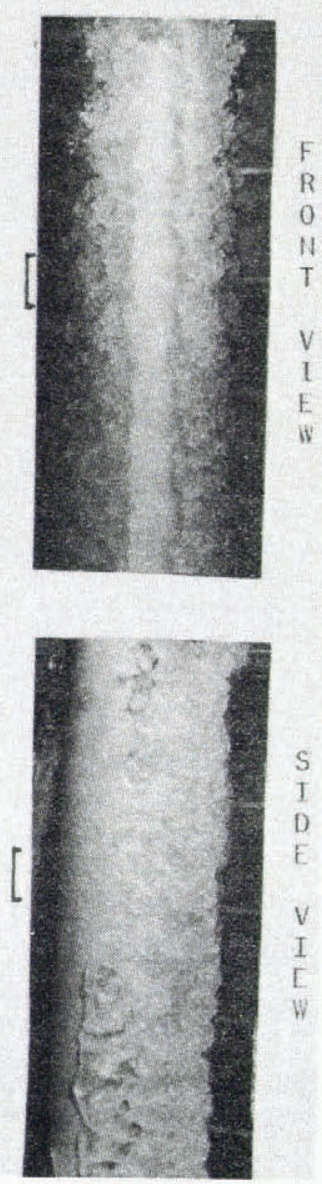

Fig. 5. Icing deposits grown under conditions of various liquid water contents, and at $10 \mathrm{~m} / \mathrm{s}$ wind 


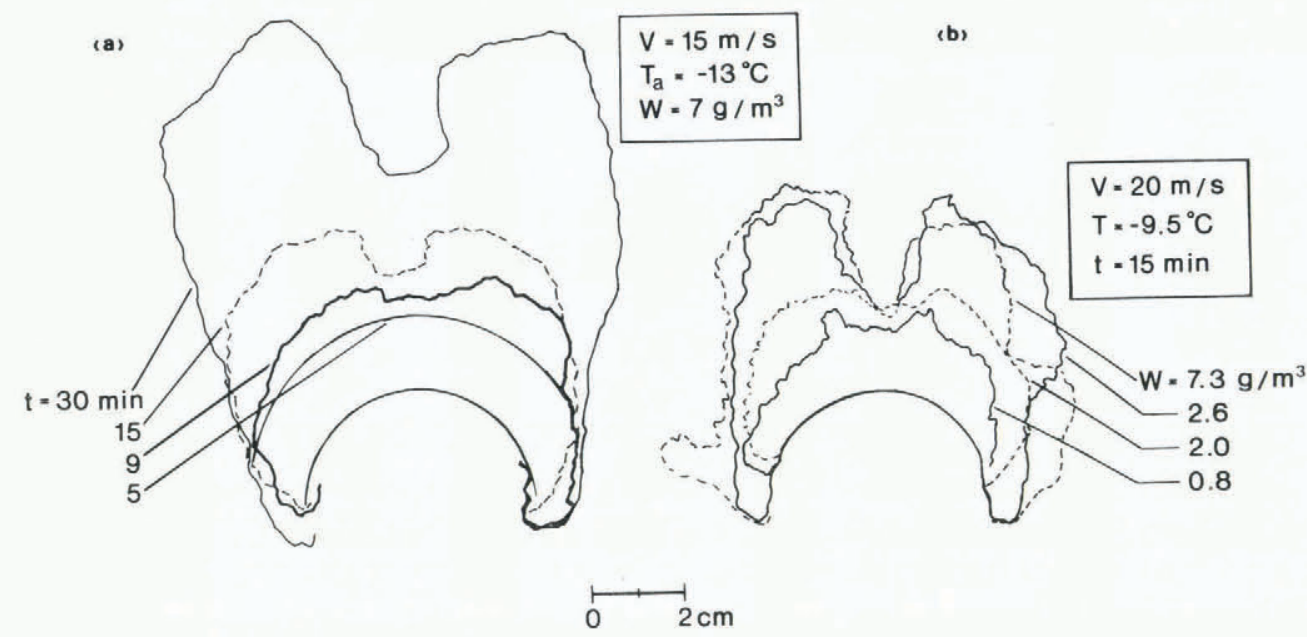

Fig. 6. Examples of dependence of cross-section of a deposit on time (a) and on liquid water content (b). (The above is based on thin sections and in detail they may not be strictly representative of a whole deposit.)

paper) a stagnation hill grows instead of a hollow, due to a higher collection efficiency of water droplets in that area.

Figures 7 and 8 give the time development of a deposit's width, height, and mass for various experimental conditions. After the first few minutes, the size and mass growth seem to be rather linear with time. Time development before that seems to be linked principally with time variations of the heat-transfer coefficient (cf. Part $\mathrm{I}^{\mathrm{T}}$ of this study; Launiainen and Lyyra, 1986).

Figure 9 shows an apparent effect of the liquid water content on the dimensions of a deposit. For high air temperatures, for low wind speeds, and for large $W$, the dependence is less prominent. Figure 9 also contains data (when considering a fixed $W$ ) of the dependence of the dimensions on air temperature, and shows a more distinct dependence when $W$ is large. Unfortunately, because of the limited data available and because of the strong dependence on $W$, we cannot provide more explicit data showing the

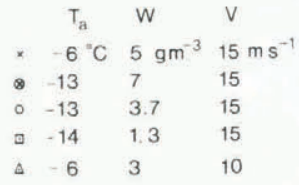

b $/ L_{c}$
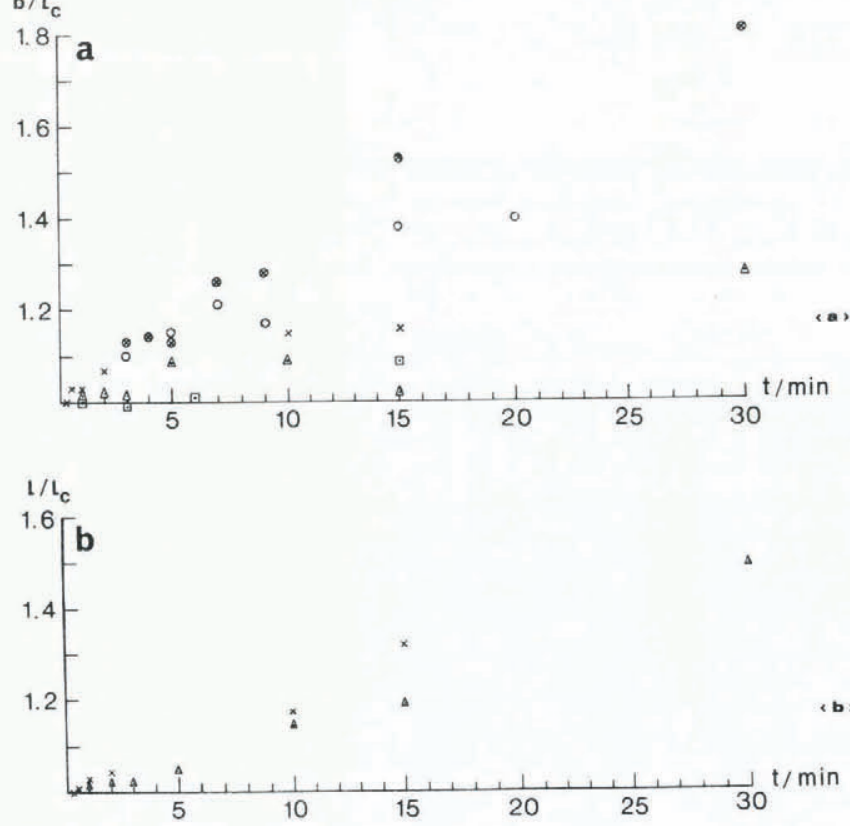

Fig. 7. Dependence of deposit width (a) and deposit height (b) on test duration for various icing conditions.

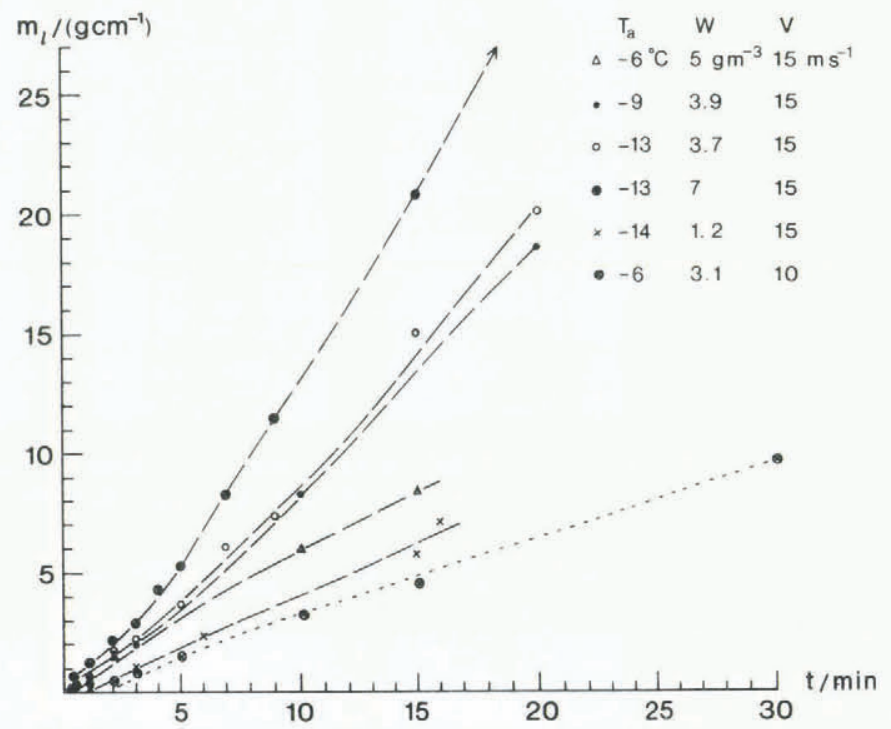

Fig. 8. Time development of deposit mass per unit length of a cylinder of diameter $5 \mathrm{~cm}$, for various icing conditions.

influence of air temperature. (For dependence of the rate of icing on air temperature, see Part II of this study.)

\section{DISCUSSION}

The above kind of icing is that typical of wet-growth conditions on stationary (vertical) cylinders. Because all the listed external quantities $\left(T_{\mathrm{a}}, V, W, t\right)$, when existing in their natural range of variation, are of the same order of importance as affecting factors, it is extremely difficult to give a comprehensive description for each factor.

Generally, however, we may conclude that an increase in liquid water content increases the width of a stagnation hollow (Figs 4 and 5) and enlarges its dimensions (Figs $6 \mathrm{~b}$ and 9), run-off, and protuberances on the sides. A decrease in air temperature enhances the rate of growth and enlarges the dimensions (Figs 8 and 9), and seems to speed up the time development described, during the first few minutes of icing. An increase in wind speed seems to have a similar effect but, because of a close link with the effects of $W$ due to mass flow $W V$, and because of variations in the shear and heat-transfer coefficient, the role of wind speed is so far the most uncertain one.

The role of a water film under which a deposit grows seems to be one of the most important for wet-growth icing. This recurring water film, the thickness and dynamics of which are dependent on several internal factors (object form and size, and locality of observation point with 


$\begin{array}{lll} & T_{a} & V \\ \bullet & -13--14{ }^{\circ} \mathrm{C} & 15 \mathrm{~m} / \mathrm{s} \\ . & -11--13 & 15 \\ -6 & 15 \\ \text { ๑ } & -9 & 20 \\ \Delta \quad-9--11 & 7.5\end{array}$

$\mathbf{b} / \mathbf{l}_{\mathbf{c}}$
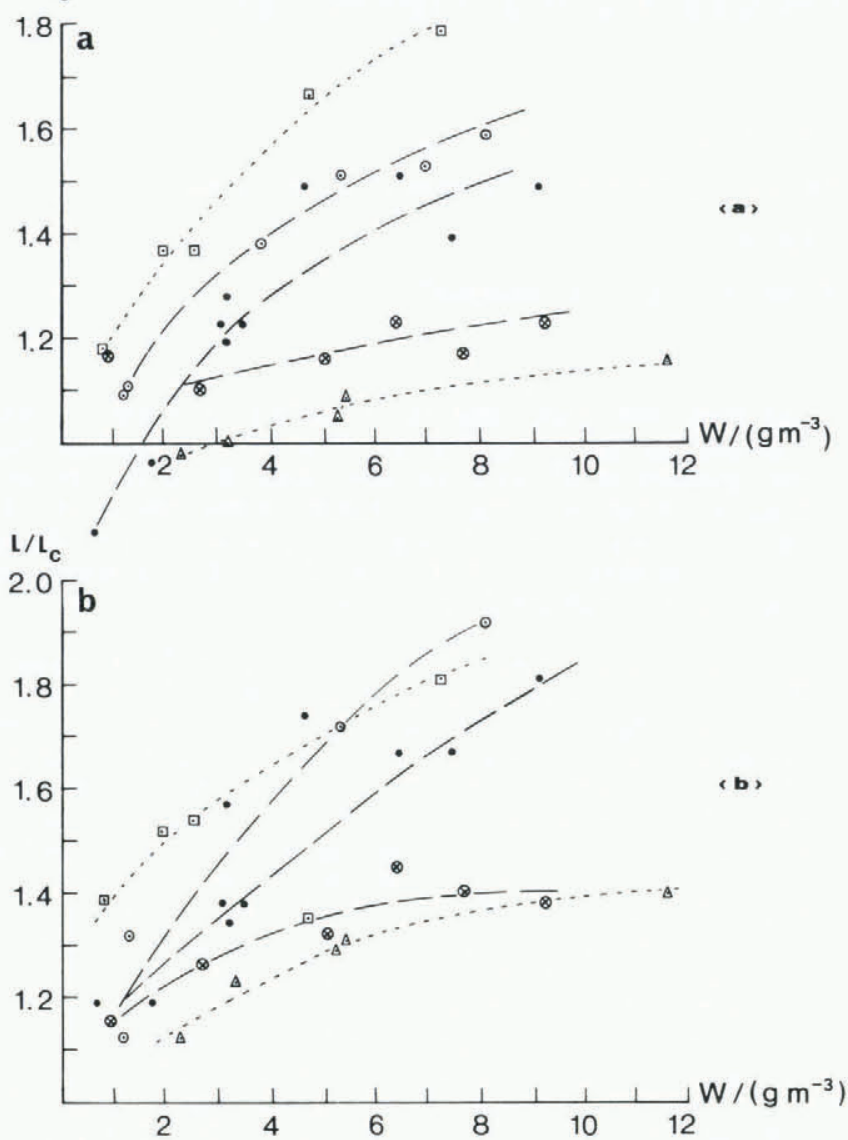

Fig. 9. Dependence of deposit width (a) and deposit height (b) on the liquid water content in the air for various icing conditions. Test duration $15 \mathrm{~min}$.

respect to shear) and external factors (primarily $W$ and $V$ ), controls the heat transfer (cf. Part II) and the form and growth charcteristics. For example, the first small protuberances during the early stages of icing have to grow through this film, moved by shear and gravitation, after which the protuberances themselves begin to have an effect on the thickness and dynamics of this film, affecting the further accretion process.

Two more characteristics of our experiments should be mentioned. First, the formation of spongy ice (List, 1977) did not seem to take place in these experiments. When handling (cutting) the deposits for quantitative measurements immediately after the tests, water was not observed inside them, at least in cases of low temperatures, i.e. below $-5^{\circ} \mathrm{C}$. This finding is also obvious from the heat-transfer coefficient results (see Part II). These results have been calculated from the mass-growth results and show no systematic dependence on air temperature, which might, in the opposite case, support the formation of spongy ice with increasing temperature. During tests at high temperatures or with saline water, the formation of spongy ice was more frequent.

Finally, in the stationary wetting tests, we did not find a sharp transition from wet growth to dry growth as speculated in several studies on icing. However, when icing an object of large thermal capacity, the early stage of the process was frequently observed to be dry, after which it transformed to a wet stage but did not return to a dry one. Actually, we need further data concerning conditions around the critical water-content region for final conclusions.

\section{ACKNOWLEDGEMENTS}

The wind tunnel was designed primarily by Professor $\mathrm{S}$. Laine, Technical University of Helsinki, and constructed by Techn. Juhani Malinen, Kevra Co. The Finnish National Board of Navigation offered room for the wind-tunnel laboratory. The assistance of $\mathrm{Mr} \mathrm{M}$. Jäntti in performing the experiments is kindly acknowledged. The study was supported financially by the Finnish Academy.

\section{REFERENCES}

Ackley, S.F., and Templeton, M.K. 1979. Computer modeling of atmospheric ice accretion. CRREL Report 79-4.

Bain, M., and Gayet, J.F. 1982. Aircraft measurements of icing in supercooled and water droplet/ice crystal clouds. Journal of Applied Meteorology, Vol. 21, No. 5, p. 631-41.

Cansdale, J.T., and McNaughtan, I.I. 1977. Calculation of surface temperature and ice accretion rate in a mixed water droplet/ice crystal cloud. Farnborough, Royal Aircraft Establishment. (Technical Report 77090.)

Langmuir, I., and Blodgett, K.B. 1946. A mathematical investigation of water droplet trajectories. Washington, DC, Department of Commerce. Office of the Publication Board. (Army Air Forces Technical Report 5418.)

Launiainen, J., and Lyyra, M. 1986. Icing on a non-rotating cylinder under conditions of high liquid water content in the air: II. Heat transfer and rate of ice growth. Journal of Glaciology, Vol. 32, No. 110, p. 12-19.

Launiainen, J., and others. 1983. A wind tunnel study of icing on marine structures, by J. Launiainen, M. Lyyra, and L. Makkonen. (POAC 83. The seventh International Conference on Port and Ocean Engineering under Arctic Conditions, Helsinki, Finland, 5-9 April 1983. Proceedings, Vol. 3, p. 446-57.

List, R. 1977. Ice accretions structures. Journal of Glaciology, Vol. 19, No. 81, p. 451-65.

Lozowski, E.P., and others. 1979. The icing of an unheated nonrotating cylinder in liquid water droplet-ice crystal clouds, by E.P. Lozowski, J.R. Stallabrass, and P.F. Hearty. Ottawa, National Research Council Canada. Division of Mechanical Engineering. Low Temperature Laboratory. (Report LTR-LT-96.)

Lozowski, E.P., and others. 1983[a]. The icing of an unheated nonrotating cylinder. Part I: a simulation model, by E.P. Lozowski, J.R. Stallabrass, and P.F. Hearty. Journal of Climate and Applied Meteorology, Vol. 22, No. 12, p. 2053-62.

Lozowski, E.P., and others. 1983[b]. The icing of an unheated nonrotating cylinder. Part II: icing wind tunnel experiments, by E.P. Lozowski, J.R. Stallabrass, and P.F. Hearty. Journal of Climate and Applied Meteorology, Vol. 22, No. 12, p. 2063-74.

Lyyra, M., and Launiainen, J. In press. Icing test performance in a wind tunnel. University of Helsinki. Report Series in Geophysics.

Panov, V.V. 1972. O raschete temperatury kapel' vody i solenosti l'da pri bryzgovom obledenenii sudov [On calculation of water droplet temperature and ice salinity during spray icing of ships]. Arkticheskiy $i$ Antarkticheskiy Nauchno-Issledovatel'skiy Institut. Trudy, Tom 298, p. 44-50. (CRREL Draft Translation, 411, 1974, p. 42-48.)

Stallabrass, J.R. 1978. An appraisal of the single rotating cylinder method of liquid water content measurement. Ottawa, National Research Council Canada. Division of Mechanical Engineering. Low Temperature Laboratory. (Report LTR-LT-92.)

Zarling, J.P. 1980. Heat and mass transfer from freely falling drops at low temperatures. CRREL Report 80-18. 